\title{
MODEL OF TEACHING GRAMMAR BASED ON APPLYING OF AN INDUCTIVE-DEDUCTIVE PROCEDURE
}

\author{
Branka Brčkalo, PhD, assistant prof. \\ Faculty of Philosophy in East Sarajevo \\ (Bosnia and Herzegovina) \\ e-mail: brankabrckalo@yahoo.com
}

\begin{abstract}
$S u m m a r y$
Many flaws of the traditional way of teaching have been overcome by applying functional procedures in approaching language phenomena and modern models of research; a new way of teaching is being created, more interesting and more effective. The model of teaching based on applying the inductive-deductive procedure offers a possibility to students to observe language phenomena within their function - in a live conversation or in a text. This kind of acting in the process of teaching helps students to build the strategy facilitating learning and remembering.

By using their preknowledge on language phenomena, students are directed to individual analyzing of examples, comparing and sorting. Eventually they go to the next step of making conclusions and definitions. This text is dealing with the application of the model based on the inductive-deductive procedure on the study of the predicator in the fourth grade of Primary School.
\end{abstract}

Key words: learning strategy, model of teaching grammar, induction, deduction, stages in the structure of the class

WHAT I HEAR - I FORGET

WHAT I SEE - I REMEMBER

WHAT I DO - I UNDERSTAND

CHINESE PROVERB

\section{Introductory remarks}

The term learning strategies, a concept that has been much used in recent decades, has many meanings which are not easy to explain. The word strategy is taken from the military terminology and derived from the Greek word strategy (military leader, general) and in the military literature it refers to the art of warfare and tactics of the army leaders to deceive the enemy.

"The term has taken on a larger meaning and denotes any global plan or methodology for achieving the main goals." (Vilotijević 1999: 598) 
Transferred to the field of learning strategy it represents the forms and methods of teaching which are mediated by educational objectives. Behaviourists, whose representatives were John Dewey, David Ousubel, Jerome Bruner, Jean Piaget, Lev Vygotsky believed that "learning is a process of interaction through which an individual builds a new understanding, suppressing or reshaping and enriching the previous conceptions. (Bruner 1976: 30).

In recent years we have seen a number of contemporary models of teaching opposing the model of the traditional way of teaching. "Pedagogy is the model which most commonly refers to the structure of educational content and features, and the processes and outcomes of the relevant structures of content." (Potkonjak, Šimleša 1989: 30)

"In order to accommodate as many individual needs of students, teachers need to master as many different methods and procedures of teaching and to use in their repertoire verbal, visual, numerical, and all other means." (Stojakovic 2000: 355)

Unlike behaviourism, cognitivism, according to Robert Gagné, involves the scientific study of mental events. Cognitive scientists argue that in the process of learning the most important thing is the mental structure of students, their thinking concept that includes not only the student's prior knowledge but also ways (strategies) of new concepts and overcoming problems.

"The strategy of learning is the way by which the student manages his own learning, based on his knowledge of his own qualities and abilities, knowledge of educational tasks which he must perform, skills of acquisition, networking and application of new knowledge, the necessary prior knowledge and understanding of the purpose and value of the new useful knowledge. During the process of learning attention must be paid to:

- habit of place;

- habit of time - scheduled daily and weekly learning;

- habit of learning during the class;

This paper will deal with the habit of learning in the process of teaching grammar and this is only a small part of the grammar learning strategies in the overall activities of the various factors which include the media, interaction between students and teachers, teaching methods, forms and means of teaching, a place (space) and time of curriculum's implementation.

On the example of the model based on the application of inductive-deductive process in teaching grammar, we will try to explain how the functional treatment helps students to build a strategy to facilitate the process of learning.

\section{Model based on the application of the inductive-deductive process}

Students see grammatical rules as a high wall which must not be jumped over, but is too difficult to be bypassed. Classes in which students had to memorize a large amount of grammar information - definitions, rules, exceptions - should belong to the past, and the task of modern education is to teach students to think, and not to remember. 
Students are nowadays in the position to acquire grammatical knowledge quickly and effectively in the classroom. The aim of education is to enable students to learn and work independently and to learn to learn properly.

One model of learning grammar in the classroom is the model based on the application of the inductive-deductive process. This model, the model set on the problem-based teaching, and learning by discovery is, according to Pavle Ilić (493), a methodical system of the modern study of grammar. Such systems banish teaching knowledge through lectures and dictation. Linguistic phenomena are not being explained to the student, but he notices, understands and explains them.

"In this way of teaching the focus is on the function and meaning of language phenomena, and their forms of expression are seen as the diversity of their functional and semantic features." (Ilić 1998: 493)

Younger students find it far more difficult to organize the acquisition of knowledge than the older ones. They are not capable of arranging, sorting and linking linguistic issues, or of spotting the similarities or differences, which is a cognitive process. "Cognition is the rational way to the truth." (Vilotijević 1999:196)

This process is very complex because it includes perception, memory, learning, imagination, discovery, opinion, concluding.

In recent years an almost disturbingly low level of acquired knowledge of grammar has been noticed. That becomes an even greater problem when the ability of students to apply that knowledge is analyzed.

The level of proficiency of students for higher levels of intellectual work (reasoning, consideration of the problem) is very low because the regular classroom work is dominated by traditional forms: lecture-test-evaluation of successful reproduction. This is why students do not create long-lasting knowledge but knowledge that lasts from one to the other tests and assessment, and as early as the next school year, students do not remember many of the teaching contents. This, among other factors, contributes to the deductive way of learning, which is still quite present in schools.

Monitoring of teaching of the Serbian language and literature in primary schools within the methodological practice of primary teaching for students shows that sometimes dictation of grammatical rules is still present. Students are introduced to the generalized knowledge and expected to accept without confirmation, based on the authority of teachers and other recognized sources of knowledge. This way rejects modern didactics and methodology of teaching language and literature, since it does not prepare students for independent learning.

Deduction is "a logical way of concluding what individual phenomena (and their cause-effect relationships) are explained based on pre-induction and reasoning of perceived thought models (concepts, laws, rules, etc.)." (Potkonjak and Šimleša 1989:269)

"Modern teaching typically aims at putting the students in a situation generalizing (concepts, laws, rules, etc.) things, based on observation and learning about individual instances." (Potkonjak and Šimleša 1989:269)

The limits of this way of learning in the classroom are clear. In order to bring out general judgements about an appearance, it is necessary to observe a large number of 
individual cases, which is impossible due to rationalization and cost-effectiveness of the teaching process. Thus resorting to short induction on the basis of selected examples is not an option. This opens the possibility of wrong choice of examples when, on the basis of wrongly selected examples, one comes to knowledge that is not scientifically based. Limitations of both these ways of learning knowledge in teaching can be overcome by their combined use.

In the model of grammar teaching based on the application of inductive-deductive procedures, students apply logical (general) methods used by other scientific disciplines in reaching findings. In this model of teaching "through the use of teaching methods (mainly text-dialogue methods and methods of demonstration) students are encouraged to observe, perceive, compare, observe the essential qualities of the linguistic phenomena and come to the definition of terms and patterns." (Ilić 1998: 494)

Such an action requires the application of logical methods, such as comparison, analysis, synthesis, concretization and abstraction, induction and deduction. The greater is the representation of independent activities in the learning process, the greater is the importance of control by the students, their self-management or control of their own learning. This is the essence of good teaching strategies. The goal is to teach children to think creatively. Students should become aware of their thinking capabilities.

"Through the process of educating students need to become aware of their own thinking process, enabled for strategic behaviour and for directing their motivation towards the desired goals." (Mirkov 2007:310)

By applying the inductive-deductive methods in teaching, the cognitive-didactic way must be achieved by applying the principle of gradual increase from known, easier and simpler content to unfamiliar, more difficult and more complex, or from talking about examples, forms and meanings to functions and definitions. It can be schematically shown as follows:

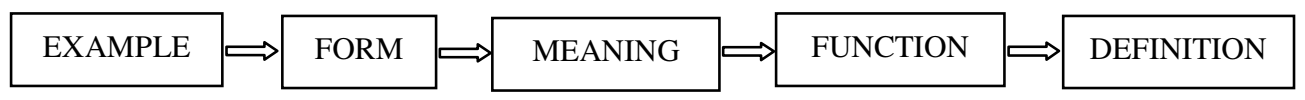

Therefore, students proceed from individual examples, to the formulation of rules, then from the rules towards substantiation of new examples and that is the inductivedeductive way of learning the language phenomena. In this way active teaching methods of working and learning are used, where students are encouraged to look for connections and relationships among data, to distinguish relevant from irrelevant facts and to keep wondering why this is happening.

It is the natural way of learning - a gradual, systematic, and mentally engaging. The naturalness of this way of learning is that the linguistic phenomena are studied on the models implemented in the text, it is language in its practical function. Students feel both the need and purpose of learning aspects of language use.

Students using the selected strategy should be trained to approach certain types of problems, as it is reflected in Project 8 of the Council of Europe in Strasbourg, 1988, p. 1-75:

"A child is not a passive recipient of information. A child seeks to integrate the information into his own conceptual system and restructure them with the help of 
cognitive strategies and prior knowledge ... contrary to Piagetian hypotheses about the egocentrism of children's thinking and inability to adapt the structure of his thinking to learning, it is today known that one of the barriers to learning occurs because children especially find it difficult to find the correct way of approaching a problem and create the wrong idea about what is the subject of learning. It is possible that there is certain disparity, at least temporal, between the path followed by the child's opinions and expectations of adults.

Baeeds on their own model of learning adults often mistakenly interpret a child's reactions.

The task of the school, and therefore the teachers, is to monitor children along this difficult and uncertain part to adoption of abstract thinking."

\section{The application of inductive-deductive process in the study of the predicator in the fourth grade of the Primary School}

If you want to successfully teach grammar, it must be presented in an interesting way. All that is unusual, new and puzzling will increase students' attention and their interest in work. We will observe the stages of the work within the structure of the lesson in which the predicator is studied using models based on inductive-deductive process.

\section{Motivation and recovery of previously acquired knowledge}

Motivation and breaking of the monotony of the lecture in which the predicator is studied can be achieved by giving a few riddles written on the board, a transparency or on paper handed out to the students. This can be the next puzzle:

It goes up the hill, but cannot be seen, it walks on water but does not make a sound. (the Moon)

It hits you but you are not able to see it. (wind)

It's walking all day, but never goes away. (clock)

It has no teeth or arms, but still bites. (winter)

Puzzles are valuable contents of folk literature, not only for the culture of expression, but they also contribute to the development of thought and reference, the search for the quick solution finding, they awaken imagination and enrich the memory, develop insight, attention and curiosity. Interest in language phenomena appears spontaneously: what was said is considered, and then what with and how it was done. They are resolved on the basis of associations by similarity and understanding of characteristic properties of objects. In this case, through fast puzzle solving, the previously gained knowledge of the subject is refreshed. Allegorical riddles and graphic expression are also explained to students. The teacher can encourage students by asking the following questions:

"Actors can be found in the answers to these riddles. Who is the actor in the first, who in the second, the third and the fourth riddle? What is another name for the actor? 
What is the subject? Is the subject the actual actor of an action or carrier of attributes in all examples listed above?"

Students come to the following observations: actors have been indentified by the words of the moon, wind, satellite, winter. Another name for the actor is the subject.

Subject is that part of the sentence who or which is the theme of he sentence. He is the actor or the carrier of some attributes. In the examples given subject is not always the actor or carrier of some attributes: the first riddle disclaims any action, and in the third a clock, as the actor, does not move anywhere, in the fourth puzzles attributes are denied to winter. However, all these words are subjects, i.e. actors, since they are the principal members of the sentence. Subject is the centre of what is expressed in the sentence. Students come to these observations when they are given the task to include the above mentioned subjects in the sentences (puzzles). Students see that there is a noun (the moon, wind, satellite, winter) at the location of the subject in all cases and that only nominal pronouns can be found in this location.

\section{Reference to a new subjectivity}

At the second stage, students are given a lingual-methodological text on which they will notice the linguistic phenomenon which needs to be studied at this point - the predicator. Grammar teaching helps students to discover how language works in $\mathrm{s}$ literary work as an artistic creation. Therefore, the task of teachers is to use literary texts in teaching grammar. as much as possible. It is sometimes difficult to coordinate the study of literary texts from the reader with the study of specific language features, since some texts are studied before and some after familiarization with a given linguistic phenomenon. In any case, it is important that the text given to students be previously analyzed and familiarized with. If the text is not familiar, it should be briefly analyzed to reveal its artistic value. To study the predicate students may be offered the text of a fable:

Frogs in search of water

The two frogs went to search for a new house since their pond had dried up. They found a well, and the first frog proposed to jump into it right away. The other said, "And what if the water dries out, how do we get out?"

Assisted by their teacher, the students will revise that a fable is a short narrative employing as characters animals, plants and objects that act like humans, revealing human characteristics, mostly their shortcomings. The teacher stimulates the students by asking: "What human characteristics do these two frogs have?" (One is frivolous, rash, the other is wise, cautious, experienced, does not make decisions quickly and thinks about the consequences.)

"What is the moral of the fable? (Nothing is to be done hastily and carelessly.)

\section{Highlighting the aim of the class}

The teacher directs students how to notice the linguistic phenomenon which needs to be explored: "What did the frogs do when the bar dried up? Find and underline all the words that denote an action." (went, found, proposed to jump, said, get out). 
These are examples of words that are related to the subject and tell them something about the subject. The word dried up denotes a state and also refers to the subject. Students are notified that the role of the word in a sentence is called the predicator. The goal is thus highlighted in a spontaneous way and is written on the board. Students formulate their own definition and record it in notebooks: Part of the sentence which says something about the subject (what it is doing, what it is like) is called the predicator.

\section{Understanding the essential properties of predicates}

The examples of predicators contained in the fable are analyzed. The students themselves observe that only verbs can be predicators in a sentence. When they have noticed that, a brief passage from Branko Ćopićs story (Mallow-Coloured Garden), which can be found in their readers, is given to them to analyze and to find the subject and the predicator of each sentence. In analyzing the students come to the conclusion that the verb "may denote a property of the subject: "The wolf is gray." Such a predicate that consists of a verb and some other words (nouns, adjectives) is called a predicate nominal, as opposed to the verb-only predicate, which consists only of a verb.

\section{Comparison and classification of examples}

Students are given the task to classify in columns all predicates in the text individually according to the scheme that they are given on the board.

\begin{tabular}{|c|c|}
\hline \multicolumn{2}{|c|}{ Predicate } \\
\hline Nominal & Verb-Only \\
\hline
\end{tabular}

Thus, students analyze, compare and classify samples; then they are able to conclude what the predicates are and how to classify them.

In the final stage of the lesson, which is the synthesis, the students individually make their own conclusions about the predicates. The conclusion to which students should come alone needs to be written, and on the basis of their written conclusion, the teacher can see which students made wrong conclusion, and help them to learn about the predicate. It is wrong when the teacher dictates the students the definition and the conclusions they came by themselves. This reverses the result of their individual work.

Model of grammar based on inductive-deductive procedures: 


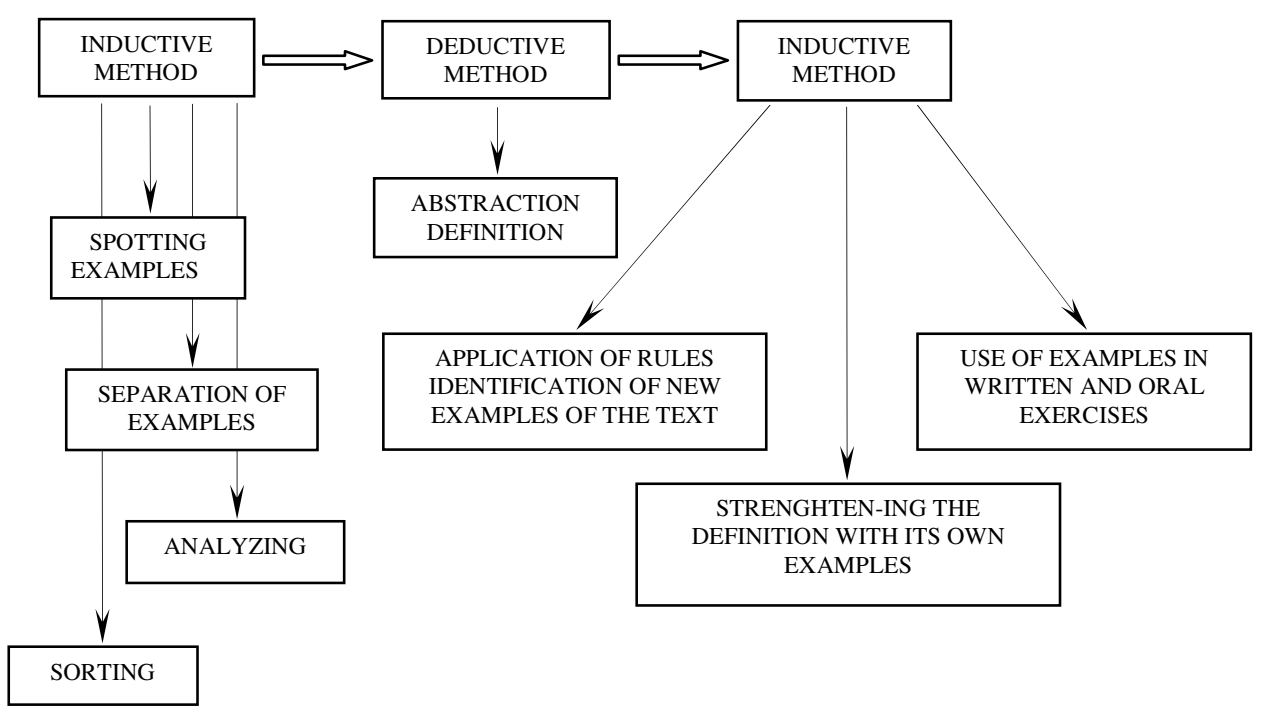

\section{Bibliography}

1. Bruner J. S. (2-3/1976), The process of education. Belgrade: Education

2.Vilotijević, M. (1999), Didactics 2 and 3 Belgrade: Institute for Textbooks and Teaching Aids. Zmaj.

3. Ilic, P. (1998), Serbian language and literature in teaching theory and practice. Novi Sad:

4. Mirko, S. (2007), Proceedings of the Institute for Educational Research. Year 39, no. 2, pp. 309-328

5. Nikolic, M. (1999), Methods of Serbian language and literature. Belgrade: Institute for Textbooks and Teaching Aids.

6. Potkonjak, N., Šimleša P. (1989), Pedagogical Commons 1 and 2 Belgrade: Institute for Textbooks and Teaching Aids, Zagreb: School.

7. Stevanović, M. (2000), Models of creative teaching. Tuzla: Publishing and trade company $\mathrm{R} \& \mathrm{~S}$.

8. Stojakovic, P. (2000), Cognitive styles and learning styles. Banja Luka: Faculty. 
Metodički obzori 6(2011)2

Pregledni rad

UDK: $371.3: 81$ '36

Primljeno: 17. 11. 2010.

\title{
МОДЕЛ НАСТАВЕ ГРАМАТИКЕ ЗАСНОВАН НА ПРИМЈЕНИ ИНДУКТИВНО-ДЕДУКТИВНОГ ПОСТУПКА
}

\author{
Дочу. др Бранка Брчкало, \\ Филозофски факултет у Источном Сарајеву \\ (Босна и Херцеговина) \\ e-mail: brankabrckalo@yahoo.com
}

\begin{abstract}
Са же е т а к
Функционалним поступцима у приступању језичким појавама и модерним моделима њиховог проучавања превазилазе се мане традиционалне наставе језика и ствара његова занимљивија и ефикаснија настава. Модел наставе граматике заснован на индуктивно-дедуктивном поступку пружа могућност ученицима да језичке појаве уочавају у њиховој функцији - у некој говорној ситуацији или тексту. Таквим поступањем у настави помаже се ученицима да изграде стратегију за лакше учење и памћење.

Коришћењем ученичких предзнања о језичким појавама, они се упућују на самостално анализирање примјера, упоређивање и разврставање, а затим приступају синтетизовању изученог и апстраховању, тј. извођењу закључака и дефиниција. Овај рад бави се примјеном модела наставе заснованог на индуктивно-дедуктивном поступку на проучавање предиката у четвртом разреду основне школе.
\end{abstract}

Кључне ријечи: стратегије учења, модел наставе граматике, индукиија, дедукција, етапе у структури часа 